\title{
CAPACITY BUILDING OF CSO ADVOCACY SKILL AND FUNDRISING UPAYA ELIMINASI TB TAHUN 2035 DI KOTA SERANG
}

\author{
Eva Fachriyah', Eva Safa'ah'2, Ratu Dea Mada Badriyah ${ }^{3}$ \\ ${ }^{1}$ Fakultas Teknologi Informasi, Universitas Serang Raya \\ ${ }^{2}$ Fakultas Teknologi Informasi., Universitas Serang Raya \\ ${ }^{3}$ D4 Vokasi, Universitas Serang Raya \\ Email: 1fachriyaheva@gmail.com, 22safaah.unsera@gmail.com, 3ratudea_30@yahoo.com
}

\begin{abstract}
Abstrak
Tuberculosa atau penyakit TB merupakan salah satu penyakit menular yang penularannya dapat dikatakan sangat cepat dan sudah dikategorikan dalam masalah kesehatan masyarakat yang membutuhkan perhatian lebih. Bahkan Badan Kesehatan Dunia (WHO) menyatakat bahwa penyakit TB masuk dalam kategori kedaruratan global bagi kemanusiaan. Ditjen P2PL Kemenkes RI dalam pedoman Pengendalian TB menyatakan juga bahwa pada tahun 2013 muncul usulan dari beberapa anggota WHO untuk mengadakan strategi baru dalam rangka pengendalian TB yang diharapkan dapat mengendalikan laju infeksi dan penularan TB. Pada wilayah yang lebih spesifik, berdasarkan data yang dilaporkan melalui website SITT (sistem informasi tuberkulosis terpadu) di provinsi Banten juga melalui penyisiran kasus di rumah sakit berjumlah 38.127 kasus atau sekitar 98\% dari target penemuan. Untuk itu, sebagai bentuk komitmen dalam rangka membantu mencanangkan gerakan Banten eliminasi TB bersama LKNU mengadakan sebuah pelatihan edukasi masyarakat tentang advokasi dan fundrising. Sejalan dengan pemerintah, LKNU melalui program TBC GF LKNU memiliki tujuan program TBC GF LKNU ini adalah membantu pemerintah dalam mencapai eliminasi TBC pada tahun 2035. Kegiatan tersebut dimulai dengan pelatihan advokasi dan fundrising.
\end{abstract}

Kata Kunci: Tuberculosis, advokasi, fundraising

\section{PENDAHULUAN}

\section{Analisis Situasi}

Sebagaimana kita ketahui bersama bahwa terdapat banyak penyakit menular dan tidak menular yang mendapat perhatian khusus di Indonesia yang menjadi masalah kesehatan masyarakat. Khususnya beberapa penyakit menular di Indonesia memerlukan keseriusan baik upaya pencegahan, pengendalian dan pemberantasannya mengingat potensi penualarannya jika tidak dibarengi dengan komitmen yang kuat dari semua tingkatan dari pasien sampai pengambil kebijakan maka akan terjadi akselerasi penularan akan lebih cepat dibanding upaya pencegahan dan penanggulangannya, salah satu diantaranya adalah penyakit menular TB (Tuberculosa). Menurut Kementerian Kesehatan RI Ditjen P2PL dalam Pedoman Nasional Pengendalian TB
(2014:2) Tuberkulosis (TB) adalah penyakit infeksi yang menular disebabkan oleh kuman kelompok Mycobacterium yaitu Myobaterium Tuberculosis. Penularan melalui udara dan sumber penularan adalah pasen $\mathrm{TB}$ yang dahaknya mengandung kuman TB. Gejala umum TB pada orang dewasa adalah batuk yang terus menerus dan berdahak selama 2 minggu atau lebih, bila tida diobati maka setelah lia tahun sebagian besar $(50 \%)$ pasien akan meninggal.

Seperti yang dinyatakan oleh Ditjen P2PL Kemenkes RI dalam pedoman Pengendalian TB (2014:5) bahwa "Pada tahun 2013 muncul usulan dari beberapa negara anggota WHO yang mengusulkan adanya strategi baru untuk mengendalikan TB yang mampu menahan laju infeksi baru,mencegah kematian akibat $\mathrm{TB}$, mengurangi dampak ekonomi akibat $\mathrm{TB}$ dan mampu meletakkan landasan ke arah eliminasi TB".Upaya percepatan Eliminasi TB akan tercapai 
bila angka insidensi TB berhasil diturunkan mencapai 1 kasus TB per 1 juta penduduk, sedangkan kondisi yang memungkinkan pencapaian eliminasi TB (pra eliminasi) adalah bila angka insidensi mampu dikurangi menjadi 10 per 100.000 penduduk. Dengan angka insidensi global tahun 2012 mencapai 122 per 100.000 penduduk dan penurunan angka insidensi sebesar 1-2\% setahun maka TB akan memasuki kondisi pra-eliminasi pada tahun 2160. Untuk itu perluditetapkan strategi baru yang lebih komprehensif bagi pengendalian $\mathrm{TB}$ secara global.( . (Ditjen P2PL Kemenkes RI, 2014)

Sejalan dengan hal tesebut Peraturan Menteri Kesehatan Republik Indonesia Nomor 67 Tahun 2016 Tentang Penanggulangan Tuberkulosis (Bab I Ketentuan Umum Ps:1) Menjelaskan :

"Penanggulangan Tuberkulosis yang selanjutnya disebut Penanggulangan TB adalah segala upaya kesehatan yang mengutamakan aspek promotif dan preventif, tanpa mengabaikan aspek kuratif dan rehabilitatif yang ditujukan untuk melindungi kesehatan masyarakat, menurunkan angka kesakitan, kecacatan atau kematian, memutuskan penularan, mencegah resistensi obat dan mengurangi dampak negatif yang ditimbulkan akibat Tuberkulosis."

Provinsi Banten berdasarkan sumber data Dinas Kesehatan Provinsi Banten, Kasus TB di Indonesia pada tahun 2017 menduduki posisi ke 8 dari seluruh provinsi di Indonesia yaitu dengan 16.608 kasus, sedangkan beban TB ini baru dicapai $42 \%$ yakni dari perkiraan kasus TB 40.277 ditemukan 17.108 kasus. Oleh karena Kesuksesan dalam penanggulangan $\mathrm{TB}$ adalah dengan menemukan penderita dan mengobati penderita sampai sembuh, maka diperlukan suatu inovasi strategi komitmen dan kebijakan pengambil keputusan seperti yang dilakukan provinsi Banten dengan melakuka Gerakan Banten Eliminasi TBC (Pencarian terduga penderita TB secara pasif,masif aktif,intensif dan masif oleh OPD dan komponen masyarakat Banten, diperiksa lab dan klinis, diobati dan dipantau sampai sembuh), hal ini juga sesuai kebijakan Kemenkes RI yang menargetkan Indonesia berhasil mengeliminasi penyakit $\mathrm{TB}$ (Tuberkulosis) pada Tahun 2030. (https://m.detik.com). Berdasarkan data dari Kemenkes bahwa jumlah penderita tuberculosis
(TBC) di wilayah Banten diperkirakan mencapai 40.227 orang, namun yang sudah terdeteksi atau terdata berjumlah sebanyak 16.608 orang, dengan peringkat pertama jumlah penderita berada di kabupaten Tangerang sebanyak 4.827 orang. (http/kabarbanten.com).

Dalam rangka ikut serta mengeliminasi TB dan sejalan dengan program pemerintah, Lembaga Kesehatan Nahdlatul Ulama (LKNU) terhitung tanggal 1 Januari 2018 - 31 Desember 2020, menjalankan mandat sebagai Sub Recipient (SR) Khusus Kementerian Kesehatan Republik Indonesia, untuk program penanggulangan Tuberkulosis (TBC) dukungan dana Global Fund. Tujuan program TBC GF LKNU ini adalah membantu pemerintah dalam mencapai eliminasi TBC pada tahun 2035. Tujuan tersebut dapat diwujudkan dengan adanya strategi nasional penanggulangan TBC yang meliputi 6 metode:

Pertama, penguatan kepemimpinan program TB di tingkat kabupaten/kota. Penguatan kepemimpinan meliputi advokasi, komunikasi dan mobilisasi sosial; regulasi dan peningkatan pembiayaan; dan koordinasi dan sinergi program.

Kedua, peningkatan akses layanan TB yang bermutu. Peningkatan layanan TB yang bermutu meliputi: peningkatan jejaring layanan TB melalui campuran pemerintah-swasta (public-private mix); penemuan aktif berbasis keluarga dan masyarakat; peningkatan kolaborasi layanan melalui TB-HIV, TB-DM, dan sebagainya; inovasi diagnosis TB sesuai dengan alat/ saran diagnostic yang baru; kepatuhan dan kelangsungan pengobatan pasien; dan kerja sama dengan asuransi kesehatan dalam rangka cakupan layanan semesta (health universal coverage).

Ketiga, promosi lingkungan dan hidup sehat; penerapan pencegahan dan pengendalian infeksi TB; pengobatan pencegahan dan imunisasi TB; dan peningkatan temuan TB secara dini, peningkatan cakupan dan keberhasilan pengobatan yang tinggi.

Keempat, peningkatan kemitraan TB melalui forum koordinasi TB yang mencakup peningkatan kemitraan melalui forum koordinasi TB di pusat dan di daerah.

Kelima, peningkatan kemandirian masyarakat dalam penanggulangan TB. Kemandirian masyarakat bisa dicapai melalui kegiatan: 
peningkatan partisipasi pasien, mantan pasien, keluarga, dan masyarakat; pelibatan peran masyarakat dalam promosi, penemuan kasus, dan dukungan pengobatan $\mathrm{TB}$; dan pemberdayaan masyarakat melalui integrasi $\mathrm{TB}$ dalam usaha kesehatan berbasis keluarga dan masyarakat.

Keenam, penguatan manajemen program, yang meliputi sumber daya manusia, logistik, regulasi dan pembiayaan, sistem informasi (termasuk pelaporan wajib kasus TB), dan penelitian dan pengembangan inovasi program.

Dari keenam strategi tersebut di atas, pelaksaan program diawali dengan kegiatan pelatihan advokasi dan fundrising, kemudian dilanjutkan dengan assessment pelayan kesehatan di puskesmas-puskesmas yang tingkat pasien TB nya masih tinggi. Kegiatan assessment tersebut merupakan rencana tindak lanjut dari kegiatan pelatihan di awal.

Dari kegiatan pelatihan advokasi dan fundrising tersebut diharapkan menjadi solusi dalam keikutsertaan program eliminasi TB 20135. Adapun peran utama LKNU sebagai organisasi masyarakat adalah untuk mendukung Kemenkes dalam menjalankan program penanggulangan TBC, khususnya untuk penemuan kasus TB, pendampingan pasien dan peran advokasi untuk peningkatan dukungan sumber daya program TB di kabupaten/ kota.Cakupan wilayah LKNU adalah 61 kabupaten di 10 Provinsi di Indonesia. Untuk pengelolaan program di tingkat region dan kabupaten/kota, LKNU menjalin kerjasama dengan CSO lainnya yaitu; PKPU, Dhompet Duafa, PPTI, Pelkesi, POP TB dan Badan otonom (Banom) PBNU yaitu PMII. Keterlibatan banyak mitra dalam pengelolaan proyek diharapkan untuk memberi kesempatan pada banyak CSO untuk mengelola program $\mathrm{CSO}$, sehingga diharapkan adanya peningkatan jumlah CSO yang mampu mengelola program dengan cakupan wilayah yang cukup luas dan anggaran yang relatif cukup besar.

Kegiatan pelatihan advokasi bertujuan mengedukasi masyarakat bagaimana melakukan advokasi terkait masalah kesehatan khususnya penyakit $\mathrm{TB}$ dalam hal pelayanan di setiap puskesmas dalam menangai pasien TB. Untuk lebih spesifik tentang tujuan dari kegiatan pelatihan advokasi dalam kegiatan ini sebagai berikut:

1. Adanya pemahaman, pengenalan, dan kesadaran tentanng kasus TB.

2. Adanya ketertarikan atau peminatan (tanpa penolakan dalam menangani kasus TB.

3. Adanya kemauan, kepedulian, dan kesanggupan dalam membantu sebuah kebijakan terkait kesehatan masyarakat.

4. Adanya tindakan nyata yang diperlukan oleh pasien TB.

5. Adanya kelanjutan kegiatan yang berkesinambungan.

\section{METODE PELAKSANAAN}

Strategi nasional penanggulangan TBC memiliki 6 metode, diantaranya:

Pertama, penguatan kepemimpinan program TB di tingkat kabupaten/kota. Penguatan kepemimpinan meliputi advokasi, komunikasi dan mobilisasi sosial; regulasi dan peningkatan pembiayaan; dan koordinasi dan sinergi program.

Kedua, peningkatan akses layanan TB yang bermutu. Peningkatan layanan TB yang bermutu meliputi: peningkatan jejaring layanan TB melalui campuran pemerintah-swasta (public-private mix); penemuan aktif berbasis keluarga dan masyarakat; peningkatan kolaborasi layanan melalui TB-HIV, TB-DM, dan sebagainya; inovasi diagnosis TB sesuai dengan alat/ saran diagnostic yang baru; kepatuhan dan kelangsungan pengobatan pasien; dan kerja sama dengan asuransi kesehatan dalam rangka cakupan layanan semesta (health universal coverage).

Ketiga, promosi lingkungan dan hidup sehat; penerapan pencegahan dan pengendalian infeksi TB; pengobatan pencegahan dan imunisasi TB; dan peningkatan temuan TB secara dini, peningkatan cakupan dan keberhasilan pengobatan yang tinggi.

Keempat, peningkatan kemitraan TB melalui forum koordinasi TB yang mencakup peningkatan kemitraan melalui forum koordinasi TB di pusat dan di daerah.

Kelima, peningkatan kemandirian masyarakat dalam penanggulangan TB. Kemandirian masyarakat bisa dicapai melalui kegiatan: peningkatan partisipasi pasien, mantan pasien, keluarga, dan masyarakat; pelibatan peran 
masyarakat dalam promosi, penemuan kasus, dan dukungan pengobatan $\mathrm{TB}$; dan pemberdayaan masyarakat melalui integrasi $\mathrm{TB}$ dalam usaha kesehatan berbasis keluarga dan masyarakat

Keenam, penguatan manajemen program, yang meliputi sumber daya manusia, logistik, regulasi dan pembiayaan, sistem informasi (termasuk pelaporan wajib kasus TB), dan penelitian dan pengembangan inovasi program.

Pelatihan advokasi ini dilaksanakan dengan kerangka dasar pendekatan orang dewasa (adult education). Asas pelatihan ini mengharuskan peran serta aktif setiap peserta. Setiap peserta diharapkan dapat saling menuangkan pengalamannya secara sistematis dan berstruktur (structure experienced). Proses ini diawali dari kegiatan melakukan, mengungkapkan, menganalisis, menyimpulkan, dan mencoba melakukan kembali untuk kemudian direfleksikan menjadi kegiatan/sikap ataupun kajian baru.

Dari sekuensi dan tahapan ini, diharapkan para peserta akan sampai pada situasi kesadaran tertentu terhadap setiap kasus/masalah yang dibahas dan didiskusikan bersama melalui kelompok maupun dalam diskusi pleno. Karenanya, pelatihan ini mencoba meminimalisir kegiatan ceramah dari narasumber tertentu, sebaliknya memberi sebanyak mungkin kesempatan tanya jawab.

Dengan semakin banyak mengajukan pertanyaan, diasumsikan peserta semakin banyak mengetahui sesuatu dan sebaliknya juga banyak yang belum dipahami. Jadi semakin bertanya bukan karena bodoh, tetapi semakin sadar bahwa dirinya harus banyak mengetahui. Sumber informasi utama dalam proses belajar ini, adalah akumulasi pengalaman para peserta itu sendiri yang telah diformulasikan secara sistematis.

Pengungkapan pengalaman para peserta adalah modal dasar dan acuan dari setiap pokok bahasan. Diasumsikan, tidak satupun peserta yang hadir dalam keadaan (seperti) "botol kosong" tanpa pengalaman. Dan tidak pula yang dalam keadaan berisi penuh dengan pengalaman di bidang advokasi. Keragaman inilah yang menjadi tugas pelatihan untuk menjadi wahana proses penuangan dan pengisian kembali secara sadar. Meskipun disadari, sulit kiranya dicapai sebuah kondisi yang beragam, baik isi dan volumenya. Pada akhirnya, heteroginitas latar belakang sosial-budaya setiap peserta sangat memungkinkan adanya perbedaan output yang dicapai.

Menganalisis informasi yang bersumber dari para peserta dalam konteks pokok bahasan tertentu menjadi penting. Di sini akurasitas pengalaman yang terungkap merupakan elemen korektif untuk menemukan sumber belajar yang sah dan diakui bersama. Sumbang saran dalam proses diskusi dilaksanakan melalui kelompok kecil yang terkadang dilanjutkan dalam kelompok besar/pleno.

Menyimpulkan hasil proses analisis merupakan pendekatan berikutnya. Pada tahap ini, para peserta diharapkan dapat secara kritis merumuskan substansi maupun nuansa pembahasan dan analisis yang telah dilakukan sebelumnya. Pokok-pokok kesimpulan ditawarkan kepada peserta dan diuji kembali kebenarannya secara bersama pula. Tugas pokok fasilitator dalam tahap ini, adalah mencatat proses dan hasil pembahasan di kertas plano yang kemudian ditempel di dinding ruang pelatihan.

Dengan harapan, kesimpulan ini akan menjadi rujukan pada setiap pembahasan materi berikutnya. Melakukan kembali di dalam forum pelatihan ini, merupakan tahap terpenting.

Di sini setiap peserta akan menggabungkan elemen kognitif dan afektifnya di dalam sebuah uji coba praktis dalam pokok bahasan tertentu. Kegiatan ini akan dilakukan secara individual, kelompok kecil maupun dalam kelompok besar.Merefleksikan hasil suatu kerja individual maupun kelompok juga penting. Di sini pemahaman substansial setiap peserta dipertaruhkan. Kriteria penilaiannya adalah korelasi antara pengalaman kerja praktis dan formulasi refleksi pribadi yang ditampilkan. Pertanyaannya kemudian adalah, apakah pengalaman kerja tersebut dapat melahirkan inovasi baru atau tidak dalam pelaksanaan peran dan tugas di lapangan. Dan yang lebih penting, apakah ada komitmen (pengikatan diri) para peserta untuk mengaktualisasikannya dalam suasana dan nuansa kelompok di wilayah kerjanya sebagai tindak lanjut pelatihan ini.

\section{HASIL DAN PEMBAHASAN}

Dalam kegiatan pengabdian ini, peserta berasal dari kabupaten Serang dan kota Serang yang dibuat dua kelas dari berbagai unsur seperti tokoh masyarakat, LSM yang bergerak dan peduli dengan 
kesehatan, mahasiswa, dan kader puskesmas. Ketika kegiatan pelatihan ini berlangsung respon peserta sangatlah aktif dan suasana kekeluargaan pun tercipta karena dari berbagai unsur masyarakat memiliki tujuan yang sama yakni peduli terhadap kesehatan masyarakat terutama penyakit TB.

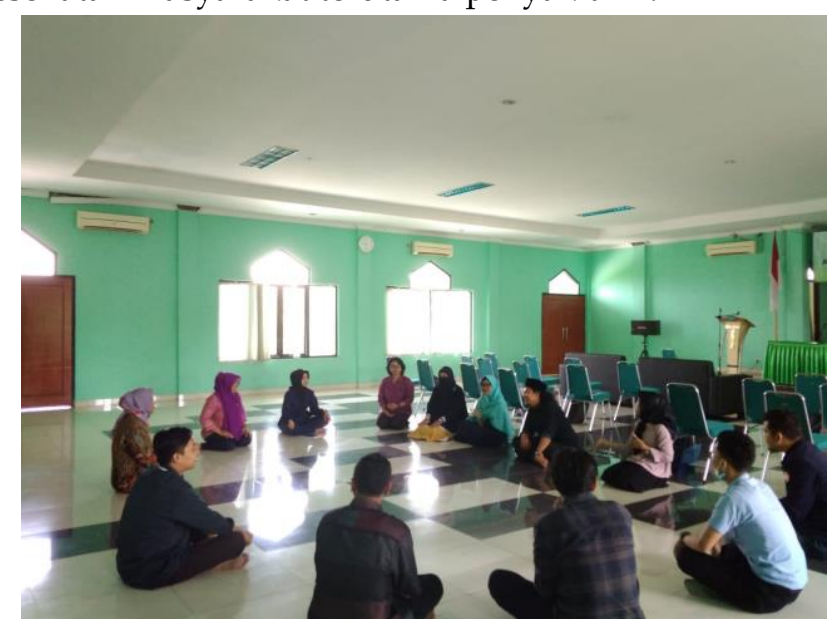

Gambar 1. Sesi perkenalan dan pengenalan materi

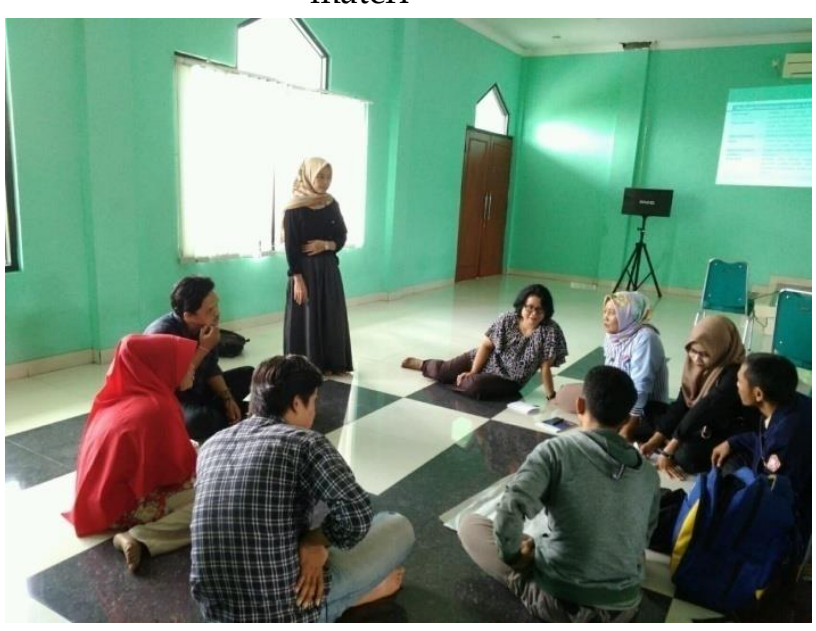

Gambar 2. Suasana pelatihan advokasi dan fundrising

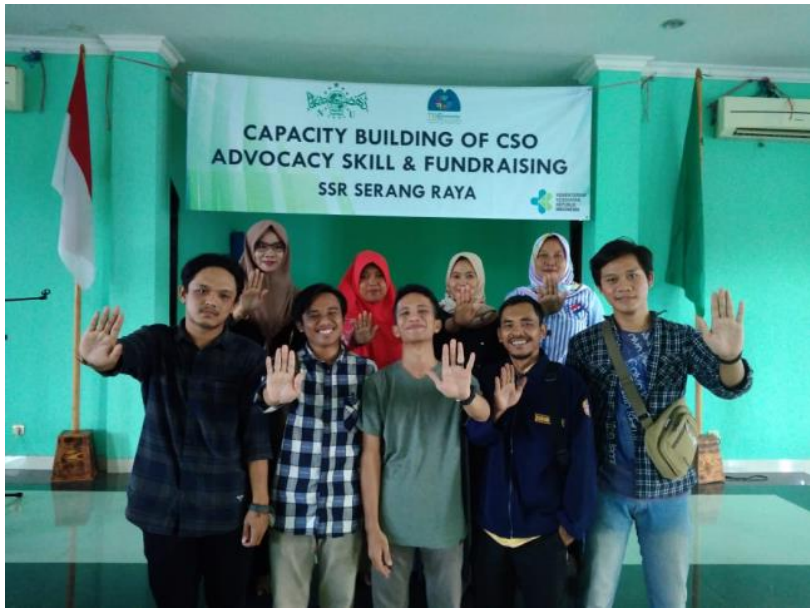

Gambar 3. Sesi akhir pelaksanaan pelatihan
Berdasarkan uraian metode pelaksanaan di atas, maka teknis atau bentuk-bentuk kegiatan sepanjang pelatihan ini adalah sebagai berikut:

- Sumbang saran

- Diskusi kelompok

- Diskusi pleno

- Kerja mandiri

- Kerja kelompok

- Meta plan

- Telaah kasus

- Simulasi/business game

- Presentasi

Teknik kuliah, ceramah masih diperlukan untuk materi yang memerlukan penjelasan. Dalam kuliah atau ceramah, tetap dipandu oleh moderatorsedemikian rupa sehingga lebih banyak tanya jawab yang memungkinkan peserta lebih aktif.Peralatan yang dipergunakan tidak perlu mewah dan serba ada, melainkan disesuaikan dengan kondisi setempat dan kreativitas Fasilitator. Peralatan-peralatan tersebut dibedakan:

Peralatan ruang, antara lain:

- White board

- Flip chart

- Komputer set serta data traveller

- Overhead projector atau LCD

Peralatan latihan, antara lain:

- Plano koran

- HVS folio

- Kartu dari manila karton

- $\quad$ Spidol untuk kertas (besar)

- $\quad$ Spidol white board (besar)

- Cutter/gunting

- Lak band/selotip keras/double tape

- Disket/flash disc (data traveller)

- Stapler

Peralatan peserta, antara lain:

- Block note

- Alat tulis

- Bahan bacaan

- Tas/map/ordner

\section{Fasilitator}

Guna mencapai tujuan pada setiap pokok bahasan secara optimal, peserta latihan didampingi seorang fasilitator. Narasumber diperlukan untuk menambah wawasan, baik wawasan tentang program, pendamapingan serta pengetahuan advokasi yang sangat diperlukan dlam melaksanakan peran dan tugas di lapangan.

\section{Peserta}

Peserta Latihan Advokasi Peogram TBC GF LKNU ini seluruhnya sebanyak 15 orang yang berasal 
berbagai instansi atau lembaga yang ada di kota Serang.

\section{Waktu Dan Tempat}

Pelatihan ini dilaksanakan di kota Serang, selama dua hari, adapun jadwal Latihan Advokasi Program TBC GF LKNU tersebut sebagai terlihat di halaman berikut, namun tidak menutup kemungkinan dilakukan penyesuaian terkait kondisi saat pelaksanaan pelatihan.

\section{Ucapan Terima Kasih (jika ada)}

Pada kesempatan ini tak lupa kami haturkan terimakasih kepada semua pihak yang terlibat terutama tim pendukung pelaksana LKNU kota dan kabupaten Serang, juga para peserta dari berbagai elemen masyarakat diantaranya: BEM Stkes Fatahillah, ketua paguyuban TB, rumah Fopkia, IMM Serang, LPNU kota Serang, Lazisnu kota Serang, korpri kota Serang, KSR UNIBA dan yang lainnya yang tidak bisa disebutkan satu persatu.

\section{KESIMPULAN DAN SARAN}

\section{Kesimpulan}

Dengan pelatihan advokasi dan fundrising diharapkan setiap unsur masyarakat dapat menyebarluarkan informasi yang didapat selama pelatihan kepada masyarakat yang lainnya, dapat cepat tanggap dalam membantu ketika ada permasalahan tentang kesehatan khususnya TB, dapat membuat suatu event secara mandiri dalam setiap organisasi terkecil untuk melakukan upaya mengeliminasi TB, dapat memantau pelayanan kesehatan dan segera menindak dengan melakukan advokasi.

\section{DAFTAR REFERENSI}

Direktorat Jenderal Pengendalian Penyakit dan Penyehatan Lingkungan Kemenkes RI, Pedoman Nasional Pengendalian P2 TB, Jakarta, 2014.

https://m.detik.com

$\begin{array}{lrr}\text { Keputusan Menteri Kesehatan } & \text { No. } \\ \text { 1278/Menkes/SK/XII/2009 r tentang } \\ \text { pedoman pelaksanaan }\end{array}$

Keputusan Menteri Kesehatan Republik Indonesia No. HK.02.02/MENKES/52/2015

Undang-undang No 25 tahun 2009 Tentang Pelayanan Publik.

Rencana strategis Kementrian Kesehatan tahun 2015 - 2019

Sk Menpan no 25 tahun 2005 tentang Indeks Kepuasan Masyarakat.

Antiqua 11, Reguler, spasi 1) 